The closing blossom has aforetime appealed to the imagination of nature lovers - even poets have been inspired by the contemplation of the nodding flower:

Soft shades and dews have shed their blended power

On drooping eyelid and the closing flower.

An idea offering such poetic possibilities, as that of the repose of these spring blossoms, is one, which one is naturally reluctant to pass by. To record these sleeping beauties in the tulip-form you see in the accompanying photograph, necessitated another walk after dusk, to the habitat of these comely blossoms. After the most perfect ones had been singled out by means of a flashlight and carefully carried home, they were duly photographed. Since the crocus anemone responds readily to room temperature and photo-flood lights, they were placed in a refrigerator until the camera, reflectorflood lights, and a crepe-paper background had been set up, ready for the actual photographing.

Everyone knows and loves the well-known "crocus" of the prairie. With our admiration is combined a warmer feeling, since early flowers in the first floral pageant of the year are especially welcome. They are loveable flowers: some, a charming lilac, others, blushing lavender. To complete the charm when presented in such romantic association, it is no wonder that these demure blossoms stole the hearts of the judges in a recent kodachrome slide contest. Unfortunately, the black-and-white copy from the kodachrome transparency hardly conveys the color and charm one would wish it to express.

As the flower is so bountifully endowed to ensure the successful perpetuation of its kind, let us not forget the "crocus" after the blossoms go. The feathery plume-like fruit, which appears after the true leaves are out, taking on the effect of low waves of smoke moving across the prairie, are no less calculated to call forth our wonder and admiration. May this floral gem lead us to frequent invocation to Him, who in a moment of ecstacy fashioned the flower - and when He had finished, it is recorded that He declared, "It is good."

\section{That All Might See...}

By Elizabeth Cruickshank, Regina

Are we born with a love of Nature? Or is it taught as someone has said by infection?

A grandmother told me that among her golden memories were the springtimes, for then her Danish grandfather, on whose farm they lived, gave each of the children a bird as they arrived. To them the gift was real and sad farewells were waved, each to his own, when Autumn came. "So naturally," she said "I've loved birds all my life."

For ourselves we need only to close our eyes to smell the Mayflowers of home or the fern-odours of cool dark woods, where little rustlings were a challenge for investigation; to see the abundant starry Gold-thread in the cedar swamp, the first wood Violets or Lady's Slipper or the Jack-inthe-pulpits.

How often doing the daily chores can we see the daisied fields, buttercup gold-studded; or hear the moonlight sonatas of frogs and murmuring brooks; or taste the sharp sweet low-bush cranberry or go in imagination on a nature hike, when the city confined us, with a teacher who felt the importance of hearing from the White-throats" own throat "I love Canada, Canada, Canada!" and of seeing the Trillium and the Dogtooth Violet in their own home surroundings.

But here again is Spring on the prairie! Here again is the

"Brown earth yielding birth

To the laughing legions

Of Spring's mirth."

Crocuses everywhere! Judy in the Valley watching her young visitors to see that only one blossom is picked from the large clumps - none from the small ones. She is of Millay's mind

"I will be the gladdest thing under the sun -

I will touch a hundred flowers And not pick one."

Today the Box-Elder at my kitchen window prepares its display of flimsy cascades of green and gold. A little company of Myrtle Warblers investigate the bushes in the yard. A robin splashes with a song sparrow 
in the bath, our two-year old trying to join them. Where were they when the bath was ice-bound, we wonder!

Last week by the Wascana we saw our first Towndsend's Solitaire. Peterson terms it a "confusing bird" and "Taverner" a bird typical of high mountain solitudes, surrounded with an air of mystery that piques the imagination."

Why here - now?

Perhaps there is our answer to why once nature-lovers, always nature-lovers: the mystery and the beauty of it.

Einstein said "He who can no longer pause to wonder and stand rapt in awe, is as good as dead, his eyes are closed."

This seeking and wonderment in the pulsing life all about us in the great outdoors is ours to share to light a spark to tinder perhaps, for out of experience we have learned that

"What thou lovest well, remains, the rest is dross."

\section{The Husbandman}

\section{By Rose McLaughlin, Indian Head,} Sask.

In Bible times the farmer was called a husbandman, because in that primitive, pastoral setting men were more sharply aware than we are tcday of the relationship between humankind and the nurturing soil. For the earth is very feminine - beautiful, fruitful, sustaining, growing more lovely the more it is loved, but becoming harsh, ugly and barren when it is prostituted by greedy men.

When I was a child I used to pass by a spring on my way to school. The first green grass of the year grew tender on its lip, birds built in the willows on its bank, and crops grew lush in the field around it. But every year men sheared closer and closer, breaking the flowered sod at last to its brink. Then came the drouth of the thirties, and the blowdirt formed a scum on the face of that beautiful, life-giving pool, choking, blinding, burying it, 'till. nothing remains today but a rough, weedy hollow in a field.

Springs are not plentiful on the prairie, but many years later I found another. Great trees flung their

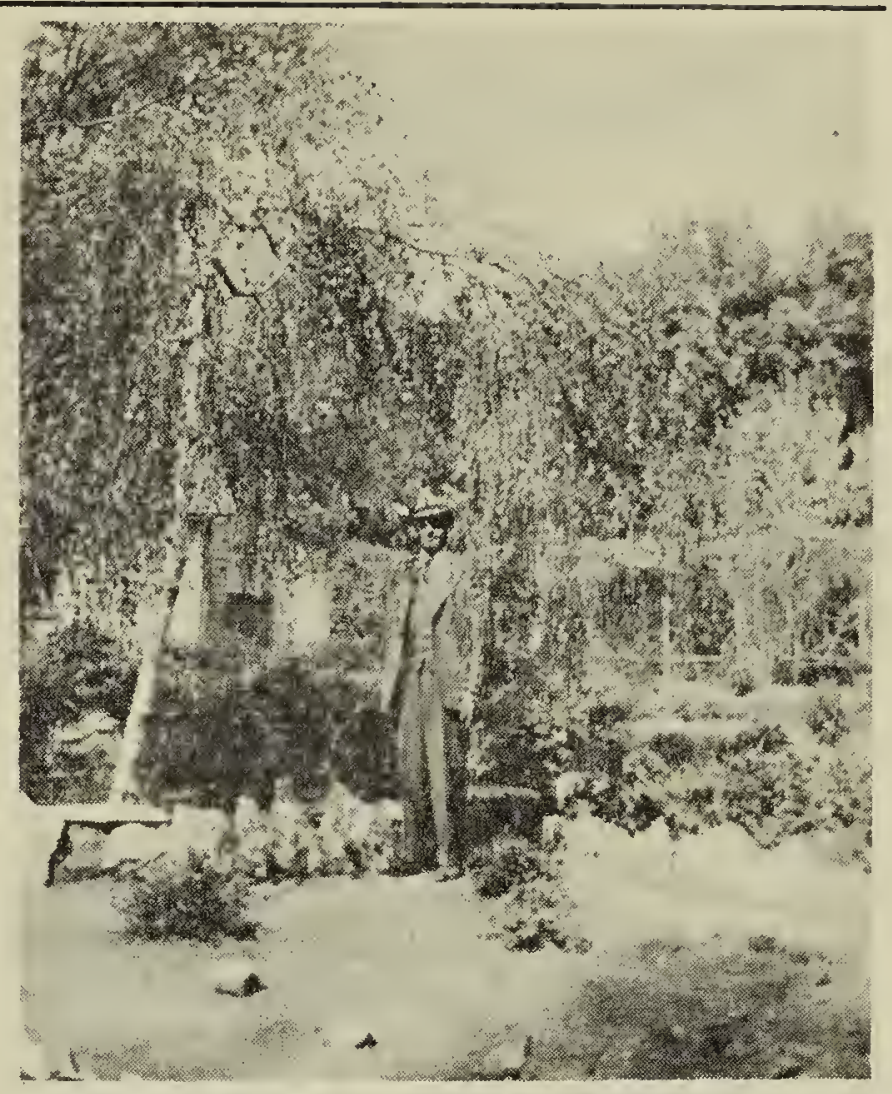

Frank Wilson of Caron, Sask, and the "Weeping Birch" in his garden.

branches across it and the surrounding shelterbelts protected within their walls an orchard and a terraced flower garden, and between the two a wide, sunny picnic ground. Down through the years, while the evergreens grew higher, and the orchard grew wider, and the lily pond came into being, and the weeping birch grew up beside it, and the familiar flowers $\mathrm{m}$ ad e room for exotic strangers, visitors have flocked to the place, drawn by its ever-changing, never-ending charm - the flowering and fading, the fruiting and falling, in a kaleidescope of loveliness.

And during the dry years, when the ravaging winds scoured great pits in the over-cropped soil of the surrounding farmlands, this spring with its encircling gardens became a sanctuary of beauty - beauty evoked by a man who loved and appreciated and husbanded his land.

It is exactly fifty years since the owner, an emigrant from Edinburgh, Scotland, discovered the spring on the quarter east of his homestead, and bought the land, as being an ideal location for a scheme he had in mind. For the garden he created there existed first in his heart just as the deserts which stretch across the once-fertile plains of North Africa and Central Asia were created by men with deserts in their. hearts. 